\title{
Assessment of blood clot formation in patients with Primary Sjögren's syndrome (pSS)
}

\author{
K Collins ${ }^{1 *}$, K Balasubramaniam ${ }^{1}$, B Griffiths ${ }^{2}, G$ Viswanathan² ${ }^{2}$ A Natasari ${ }^{1}$, J Tarn ${ }^{1}$, A Zaman², WF Ng ${ }^{1}$ \\ From Northern and Yorkshire Deaneries Annual Rheumatology Conference \\ York, UK. 26 September 2012
}

\section{Background}

Primary Sjögren's syndrome (pSS) is an autoimmune rheumatic disease affecting the exocrine glands. Several pSS-associated clinical and laboratory parameters may predispose to thromboembolic risk, however clinical data is conflicting.

My primary objective was to test whether whole blood clot formation is abnormal in pSS using several complementary approaches: Thromboelestrography (TEG) and Multiplate platelet mapping (MPP) for pSS patients compared to healthy and disease (lupus-SLE) controls and compare the size/composition of blood clots formed ex-vivo between pSS patients and healthy controls using a clotting chamber, which simulates the clotting process in-vivo.

My secondary objectives were to determine if any clin$\mathrm{ical} /$ laboratory/cytokine parameters were associated with abnormal clotting.

\section{Methods}

TEG and MPP were performed on blood samples from 12 healthy controls, 24 pSS and 11 SLE patients.

For TEG: clot formation speed, strength and lysis rate were analysed. For MPP, platelet receptor responses to common agonists were investigated.

12 pSS patients completed a clotting chamber procedure.

Univariate correlation analysis was used to determine the relationship between clotting and clinical/laboratory/ cytokine parameters.

\section{Results}

All TEG and MPP parameters were similar between groups. Statistically significant correlations were found

${ }^{1}$ Musculoskeletal Research Group, Institute of Cellular Medicine, Newcastle University, UK

Full list of author information is available at the end of the article for (a) ESR and clot lysis parameters ( $<<0.007)$; (b) $\mathrm{CD} 40 \mathrm{~L}$ and clot formation/lysis rate $(\mathrm{P}<0.01)$.

Analysis of clot specimens from the clotting chamber is on-going. Preliminary data indicate that several cytokines are "consumed" during the clot formation.

\section{Discussion}

There was no difference in clotting and platelet receptors function between pSS patients and lupus patients/ healthy controls. Interestingly, several laboratory/clinical parameters significantly correlate with clotting/platelet receptor function.

\section{Author details}

${ }^{1}$ Musculoskeletal Research Group, Institute of Cellular Medicine, Newcastle University, UK. ${ }^{2}$ Freeman Hospital, Newcastle upon Tyne, UK.

Published: 14 February 2013

doi:10.1186/1471-2474-14-S1-A15

Cite this article as: Collins et al:: Assessment of blood clot formation in patients with Primary Sjögren's syndrome (pSS). BMC Musculoskeletal

Disorders 2013 14(Suppl 1):A15.

Submit your next manuscript to BioMed Central and take full advantage of:

- Convenient online submission

- Thorough peer review

- No space constraints or color figure charges

- Immediate publication on acceptance

- Inclusion in PubMed, CAS, Scopus and Google Scholar

- Research which is freely available for redistribution
C Biomed Central

C 2013 Collins et al; licensee BioMed Central Ltd. This is an Open Access article distributed under the terms of the Creative Commons Attribution License (http://creativecommons.org/licenses/by/2.0), which permits unrestricted use, distribution, and reproduction in any medium, provided the original work is properly cited. 